\title{
Stability of antimicrobial activity of cryptdin-2 against selected pathogens under physiological conditions
}

\author{
Simran Preet, Ram Prakash Tiwari, Praveen Rishi* \\ Department of Microbiology, \\ Basic Medical Sciences Block, Panjab University, Chandigarh, INDIA-160014
}

\begin{abstract}
Background and Objective: An initial step prior to clinical development of any therapeutically active peptide is to evaluate its stability under physiological conditions. As cationic antimicrobial peptides have been reported to lose their activity under physiological conditions, present study was done to evaluate the stability of antimicrobial activity of cryptdin-2 (a Paneth cell antimicrobial peptide) against Salmonella Typhimurium, Yersinia enterocolitica and Staphylococcus aureus in the presence and absence of physiological concentrations of bile salts, monovalent and divalent cations, trypsin as well as at various $\mathrm{pH}$ values.
\end{abstract}

Methods: The antimicrobial activity of cryptdin-2 under various physiological conditions against Salmonella Typhimurium NCTC 74, Yersinia enterocolitica and Staphylococcus aureus was evaluated by use of a modified broth dilution technique

Results: Interestingly, the activity of the peptide against the Gram negative strains was augmented by bile salts while no change in the activity against $S$. aureus was observed. Though there was a decrease in activity with increasing concentrations of metal ions, the activity was not completely lost. The peptide was able to sustain its activity against all the three test strains at physiological concentrations of trypsin. At $\mathrm{pH} 8$, no change in activity was observed against $Y$. enterocolitica and $S$. Typhimurium while it was found to be reduced against $S$. aureus.

Interpretation and Conclusion: The study provides data showing the stability of the peptide under the physiological conditions and indicates towards the possibility of developing it as an alternate strategy to combat bacterial pathogens.

Keywords: antimicrobial activity, bacterial pathogens, cryptdin-2, physiological conditions, stability.

\section{INTRODUCTION}

The emergence of bacterial resistance to common antibiotics poses a serious threat to human health and has rekindled interest in the development of novel therapeutic agents having broad antimicrobial mechanism viz. conventional antibiotics. ${ }^{1}$ In this regard, cationic antimicrobial peptides (AMPs) also called defensins, of eukaryotic origin have gained considerable interest and are considered potential candidates as new therapeutic agents against bacterial infections. ${ }^{2}$

\section{Corresponding Author :}

Dr (Mrs.) Praveen Rishi, Ph.D, FAMI,FABMS

Email: rishipraveen@yahoo.com

Department of Microbiology

Basic Medical Sciences Block

Panjab University, Chandigarh - 160014, India

Tel: +91-172-2534146

Fax: +91-172-2541770
AMPs are effector molecules of the innate immune system and possess direct antibacterial and immunomodulatory properties. ${ }^{3}$ Earlier studies have indicated the in vitro and in vivo therapeutic potential of various cationic AMPs including human neutrophil peptides against bacterial ${ }^{4}$ and viral infections. ${ }^{5,6}$ The antibacterial activity of cryptdins (mouse Paneth cell defensins) has been investigated in vitro only against a few microbes. ${ }^{7}$ Recently we have reported that cryptdin2 displays a strong therapeutic activity against experimental Salmonellosis. ${ }^{8}$ This prompted us to assess the stability and sustainability of this peptide under the conditions more closely related to those encountered in vivo (as an initial step of paramount importance) prior to its clinical development as a therapeutic agent. To the best of our knowledge, the stability of antimicrobial activity of cryptdin-2 against $S$. Typhimurium, $Y$. enterocolitica and Staphylococcus aureus under the conditions mimicking the in-vivo situations has been evaluated for the first time in this study. 


\section{MATERIALS AND METHODS}

\section{Bacterial strains and growth media}

Salmonella Typhimurium NCTC 74, procured from Central Research Institute, Kasauli, India was used in the present study. This strain was maintained on MacConkey's agar medium and has been used in earlier studies both as a virulent as well as reference strain. ${ }^{8-10}$ Y. enterocolitica ATCC 23715 and Staphylococcus aureus subsp. aureus ATCC 9144 were procured from Institute of Microbial Technology, Chandigarh, India and were maintained on Tryptose agar medium containing $0.005 \%$ thiamine $\mathrm{HCl}$ and nutrient agar medium respectively. To prepare the cell suspensions, the overnight cultures were harvested by centrifugation $(3783 \times \mathrm{g}, 10$ min), washed once with $10 \mathrm{mM}$ sodium phosphatebuffered saline (PBS, pH 7.2) and resuspended in PBS. For killing assays, approx. $1 \times 10^{7} \mathrm{cfu} / \mathrm{ml}$ of $S$. Typhimurium and $S$. aureus were used while for $Y$. enterocolitica, the final cell count was adjusted to $1 \mathrm{x}$ $10^{9} \mathrm{cfu} / \mathrm{ml}$ using PBS (pH 7.4).

\section{Synthetic cryptdin-2}

Chemically synthesized peptide with an amino acid sequence of LRDLVCYCRTRGCKRRERMNGTC RKGHLMYTLCCR identical to the sequence of mouse Paneth cell cryptdin-2 with disulfide linkages between

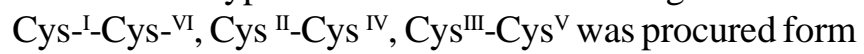
Taurus Scientific, USA. It was suspended in $0.01 \%$ acetic acid, stored as a stock solution of $100 \mathrm{mg} / 1$ at $-20^{\circ} \mathrm{C}$ and was used within three weeks.

\section{Minimum bactericidal concentrations (MBCs)}

The antimicrobial activity of cryptdin-2 against Salmonella Typhimurium NCTC 74, Yersinia enterocolitica and Staphylococcus aureus was evaluated by use of a broth dilution technique. In brief, flat-bottom tubes containing bacterial cells in Mueller Hinton Broth and peptide at different concentrations were incubated at $37^{\circ} \mathrm{C}$ on an orbital shaker until the mid-exponential phase (16-18 h). The MBC (at which there was $99.99 \%$ inhibition of growth) was calculated by monitoring the colony forming units (CFUs) at various concentrations with respect to the untreated cells. The antibacterial effect was estimated as the rate of cells surviving against the total number of cells used. In addition, growth was monitored during the mid-log phase by measuring the optical density at $620 \mathrm{~nm}$.

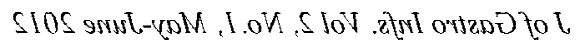

\section{Minimum bactericidal concentrations (MBCs) in presence of bile salts}

This was done by a similar method as described above with a slight modification. All the flat bottom flasks containing various concentrations of crytpdin- 2 were supplemented with $0.3 \%$ of sodium taurocholate and sodium deoxycholate. After the addition of the respective bacterial cells, these flasks were incubated under microaerophillic conditions in anaerobic jars. For determination of CFUs, $0.1 \mathrm{ml}$ of samples was plated on an appropriate agar plate for each species (MacConkey's agar for Salmonella Typhimurium, Tryptose soy broth (TSB) and Nutrient agar for $Y$. enterocolitica and Staphylococcus aureus respectively). The plates were then incubated at $37^{\circ} \mathrm{C}$ (under microaerophillic conditions) for $16-18 \mathrm{~h}$ and used for colony counts measurements.

\section{Effect of metal ions}

The effect of metal ions on the antimicrobial activity was determined at MBCs of cryptdin-2 against the test bacterial strains. Mueller Hinton broth containing cryptdin2 at its respective $\mathrm{MBC}$ against the individual bacteria was used in the assay as described above. Two monovalent cations $\left(\mathrm{Na}^{+}\right.$and $\mathrm{K}^{+}$) and two divalent cations $\left(\mathrm{Ca}^{2+}\right.$ and $\left.\mathrm{Mg}^{2+}\right)$ were used as chloride salts. $\mathrm{NaCl}$ or $\mathrm{KCl}$ was added to the media to final concentrations of 0 , 10, 50, 100, 200 and $500 \mathrm{mM}$ whereas $\mathrm{CaCl} 2$ or $\mathrm{MgCl}_{2}$ was added to the media to final concentrations of $0,1,2$, 5,10 and $20 \mathrm{mM}$. The percentage of bactericidal activity compared with that using $10 \mathrm{mM}$ phosphate buffer $(\mathrm{pH}$ 7.4) was calculated.

\section{Effect of $p H$}

The effect of $\mathrm{pH}$ on the antimicrobial activity of the cryptdin- 2 was tested by determining their MBCs against the selected pathogens at different $\mathrm{pH}$ values. The $\mathrm{pH}$ of the media was altered by adding either $5 \mathrm{M} \mathrm{HCl}$ or $\mathrm{NaOH}$. The antibacterial activity was tested at $\mathrm{pH}$ values ranging from $\mathrm{pH} 5-8$.

\section{Antimicrobial activity in presence of trypsin}

Activity of cryptdin-2 against the selected pathogens was also studied in the presence and absence of trypsin following the method by Porter et al. ${ }^{11}$ with a slight modification. Bacteria were suspended in $10 \mathrm{mM}$ sodium phosphate buffer (PB) ( $\mathrm{pH} 7.4$ ) containing 1\% TSB supplemented or unsupplemented with $25 \mu \mathrm{g} / \mathrm{ml}$ or $125 \mu \mathrm{g} /$ $\mathrm{ml}$ of trypsin and mixed with various concentrations of cryptdin- 2 and incubated for 3 hours at $37^{\circ} \mathrm{C}$. Then, the

\section{PDF created with pdfFactory Pro trial version www.pdffactory.com}


CFUs were enumerated (in triplicates) on MacConkey's agar plates after making appropriate dilutions. An appropriate dilution of the reaction mixture in PB $(100 \mu \mathrm{l})$ was plated on an appropriate agar plate for each species (MacConkey's agar for Salmonella Typhimurium, TSB for Yersinia enterocolitica and Nutrient agar for Staphylococcus aureus) and then incubated at $37^{\circ} \mathrm{C}$ overnight. Inoculum density $(\mathrm{CFU} / \mathrm{ml})$ was calculated from the number of colonies on each plate. The antibacterial effect was estimated as the rate of cells surviving against the total number of cells used.

\section{STATISTICAL ANALYSIS}

To determine the significance level of the differences observed between the samples, one way analysis of variance (ANOVA) was performed followed by pair wise comparison procedures (Tukey test) using Jandel Sigma Stat Statistical Software, version 2.0. In all cases, statistical significance was defined as $p$ value of $<0.05$.

\section{RESULTS}

\section{Minimum bactericidal concentrations (MBCs)}

Cryptdin-2 decreased the colony forming units of all the test bacterial strains in a concentration dependent manner. When Salmonella Typhimurium, Y. enteocolitica and S. aureus cells were incubated with 5, 10, 15, 20 and 25 $\mathrm{mg} / \mathrm{l}$ cryptdin-2, no visible growth was observed at concentrations $20 \mathrm{mg} / \mathrm{l}$ cryptdin- 2 for $S$. Typhimuirum, $25 \mathrm{mg} / \mathrm{l}$ for $Y$. enterocolitica and $15 \mathrm{mg} / \mathrm{l}$ for $S$. aureus. To evaluate the MBC of cryptdin-2, bacterial cells were incubated with $15,16,17,18,19$ or $20 \mathrm{mg} / \mathrm{l}$ cryptdin-2. No growth of Salmonella Typhimurium was observed when the cells were incubated with $19 \mathrm{mg} / \mathrm{l}$ and higher concentrations of cryptdin-2, indicating this concentration as the MBC (as reported earlier). ${ }^{8}$ Similarly for $Y$. enterocolitica, bacterial cells were incubated with 20 , $21,22,23,24$ or $25 \mathrm{mg} / \mathrm{l}$ cryptdin-2 and the MBC was evaluated as $24 \mathrm{mg} / \mathrm{l}$ against $Y$. enterocolitica. While for $S$. aureus, the growth was completely inhibited at $15 \mathrm{mg} /$ 1 of cryptdin-2. Therefore, to evaluate the MBC, S. aureus cells were incubated with $10,11,12,13,14$ or $15 \mathrm{mg} / \mathrm{l}$ of cryptdin-2 and the MBC against $S$. aureus was determined to be $12 \mathrm{mg} / \mathrm{l}$ (Fig.1).

\section{Effect of bile salts and microaerophilic conditions}

Cryptdin-2 decreased the colony forming units of all the test bacterial strains in a concentration dependent manner in presence of bile salts also. However, the MBCs of cryptdin- 2 against the pathogens were slightly altered in

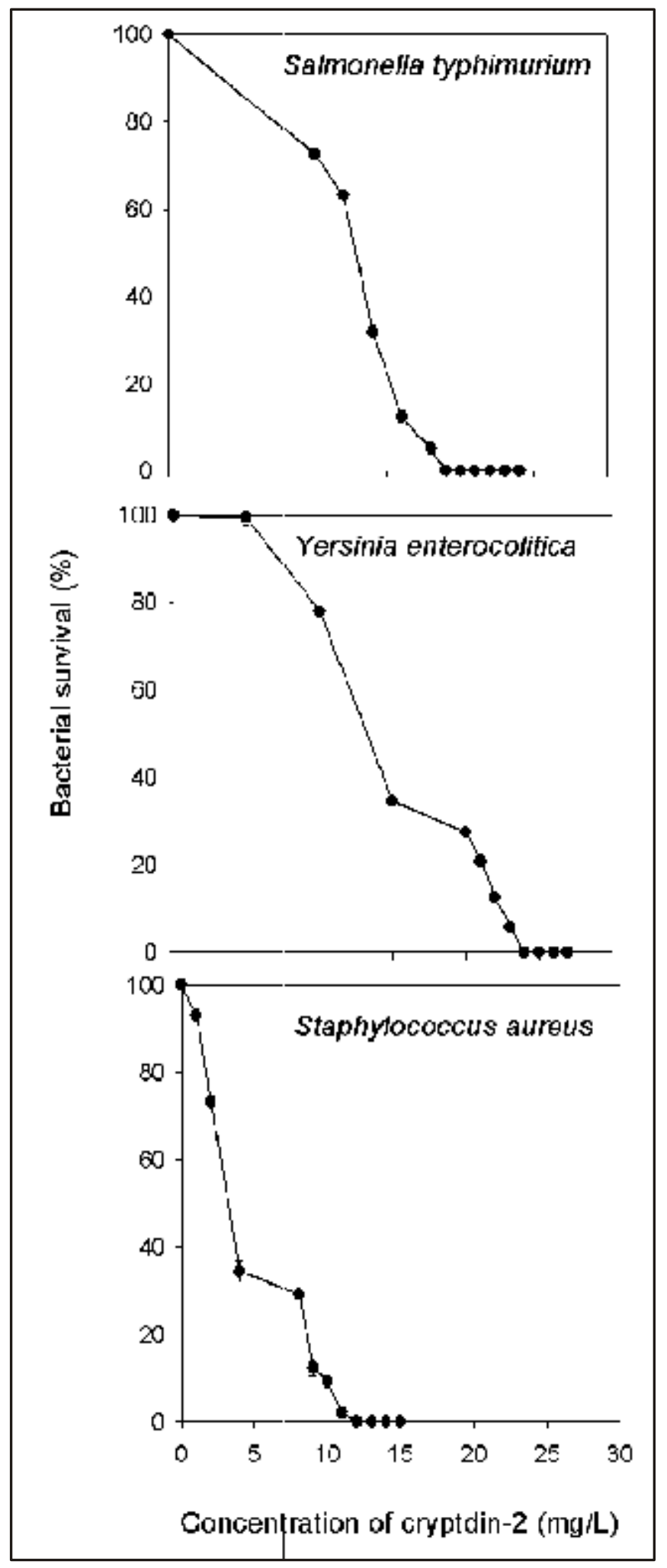

Figure-1. Antibacterial activity of cryptdin-2 against Yensinia enterocolitica, S. Typhimurium and Staphylococcus aureus. Pencentage of bacterial survival in the presence of cryptdin-2 compared with that without cryptdin-2 is represented on the longitudinal axis. The results represent the Mean \pm SD fromthree independent experiments. 


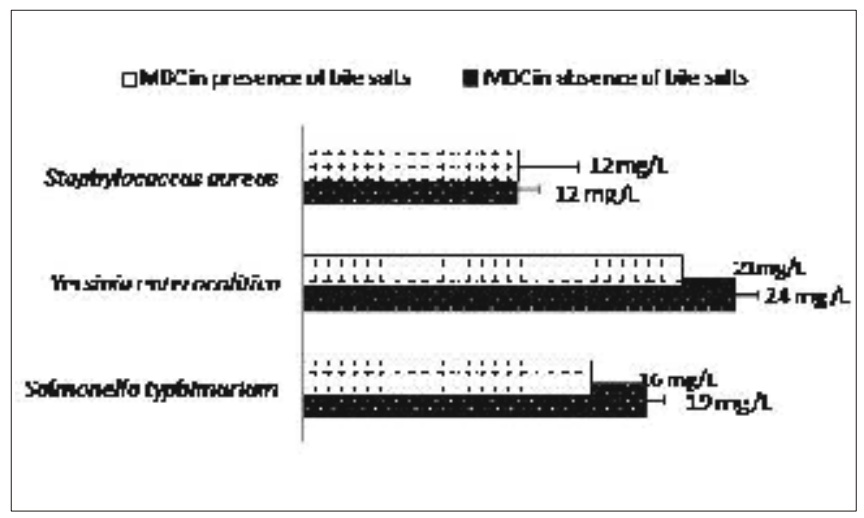

Figure-2. Minimum bactericidal concentrations of cryptdin-2 against the pathogens in presence and absence of $0.3 \%$ sodium taurocholate and sodium deoxycholate. The results represent the Mean \pm SD fromthree independent experiments.

presence of the bile salts. Interestingly, comparatively higher decrease in colony forming units at lower concentrations was observed for both $S$. Typhimurium and $Y$. enterocolitica when bile salts were added to the test medium in the presence of cryptdin-2. The MBC values in presence of bile salts were evaluated to be $16 \mathrm{mg} /$ 1 and $21 \mathrm{mg} / 1$ for Salmonella and Yersinia respectively. While for $S$. aureus, no change in MBC value of cryptdin2 in presence of bile salts was observed (Fig. 2).

\section{Effect of monovalent cations}

When the effect of monovalent cations on the antibacterial activity of cryptdin-2 was evaluated at its respective minimum bactericidal concentrations against each organism, a loss in activity was observed at higher concentrations of these ions. At $5 \mathrm{mM} \mathrm{NaCl}$, no significant reduction $(p>0.05)$ in the antimicrobial activity of cryptdin- 2 was observed against all the three pathogens. In the presence of $150 \mathrm{mM} \mathrm{NaCl}$ concentration, $50 \%$ reduction $(\mathrm{p}<0.05)$ in activity against $Y$. enterocolitica was observed (Fig.3A). However, the antibacterial activity against $S$. Typhimurium (Fig. 3B) and $S$. aureus (Fig.3C) showed 32\% (p<0.05) and 36\% reduction $(\mathrm{p}<0.05)$ respectively at $150 \mathrm{mM} \mathrm{NaCl}$. On the other hand, $5 \mathrm{mM} \mathrm{KCl}$ showed a higher influence on the bactericidal activity against $S$. Typhimurium (Fig.3B) than $S$. aureus (Fig.3C) and $Y$. enterocolitica (Fig.3A) reducing the antibacterial activity to $72.8 \%$ while for Staphylococcus and Yersinia, the activity was still $99.99 \%$ and $97.8 \%$ at $5 \mathrm{mM} \mathrm{KCl}$. However, at higher $150 \mathrm{mM} \mathrm{KCl}$ concentration, comparatively higher reduction in activity against $Y$. enterocolitica $(69 \%$ reduction) $(\mathrm{p}<0.05)$ and $S$. aureus $(64 \%$ reduction) $(\mathrm{p}<0.05)$ was observed as

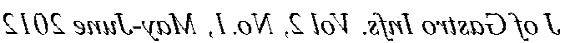

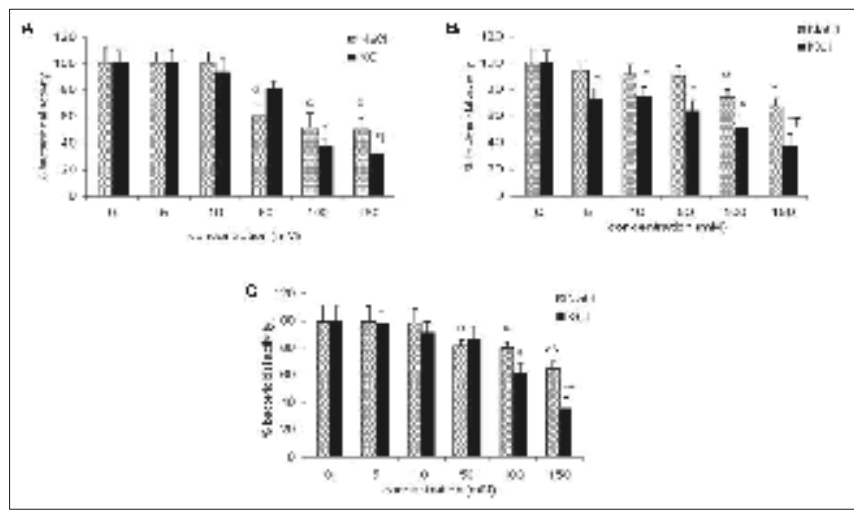

Figure-3 A). Effect of $\mathrm{NaCl}$ and $\mathrm{KC}$ on the bactericidal activity of cryptdin-2 against Y. enterocolitica. The results are means $\pm S D$ from three independent experiments. $\alpha p<0.05$ vs \% age bactericidal activity against $Y$. enterocolitica at $0,5,10 \mathrm{mMNaC} ; *_{p}<0.05$ vs. \%age bactericidal activity at $0,5,10 \mathrm{mM} \mathrm{KC} ; t p<0.05$ vs \% age bactericidal activity at $50 \mathrm{mM} \mathrm{KCl}$; $\mathrm{B}$ ). Effect of $\mathrm{NaCl}$ and $\mathrm{KCl}$ on bactericidal activity of cryptdin-2 against $S$. Typhimurium $\alpha p<0.05$ vs. \%age bactericidal activity against $S$. Typhimuriumat $0,5,10 \mathrm{mM}$ $\mathrm{NaCl} ;{ }^{*} p<0.05 \mathrm{vs}$. \%age bactericidal activity in absence of $\mathrm{KCl}$; $t p<0.05$ vs. \%age bactericidal activity at $50 \mathrm{mMKC}$; C). Effect of $\mathrm{NaCl}$ and $\mathrm{KCl}$ on bactericidal activity of cryptdin-2 against $S$. aureus. Values are means $\pm S D$ of three independent experiments. $\alpha p<0.05$ vs \%age bactericidal activity against $S$. aureus at $0,5 \mathrm{mM}$ $\mathrm{NaCl} \beta \beta p<0.05$ vs. \%age bactericidal activity at $100 \mathrm{mMNaCl}{ }^{*} p<$ $0.05 \mathrm{vs}$. \%age bactericidal activity at $0,5,10 \mathrm{mMKC}$; $\neq p<0.05 \mathrm{vs}$. \%age bactericidal activity at $100 \mathrm{mMKC}$.

compared to $S$. Typhimurium $(62 \%$ reduction $)(\mathrm{p}<0.05)$.

\section{Effect of Divalent Cations}

Cryptdin-2 was able to retain its antimicrobial activity against all the selected strains even upto $20 \mathrm{mM} \mathrm{Ca}^{2+}$ and $\mathrm{Mg}^{2+}$ ions. However, with increasing concentrations of these cations, the antibacterial activity was found to be decreased. The presence of divalent cations in the test medium had a higher influence on the antibacterial activity of cryptdin- 2 than the monovalent cations. At $1 \mathrm{mM} \mathrm{MgCl}_{2}$ concentration, no significant change $(p>0.05)$ in antibacterial activity against $Y$. enterocolitica (Fig.4A) and $S$. Typhimurium (Fig.4B) was observed, whereas the activity was reduced to $91 \%(\mathrm{p}<0.05)$ against $S$. aureus (Fig.4C). Approx. 80\% antibacterial activity was still retained against all the pathogens at about $2 \mathrm{mM}$ $\mathrm{MgCl}_{2}$. However, at $20 \mathrm{mM} \mathrm{MgCl} 2$, maximum reduction in antibacterial activity was observed against $Y$. enterocolitica (65.5\% reduction) followed by $S$. aureus (58\% reduction). Least effect of $20 \mathrm{mM} \mathrm{MgCl} 2$ was observed against $S$. Typhimurium where $38 \%$ reduction in the antibacterial activity was there. Supplementation of the test medium with $\mathrm{CaCl}_{2}$ affected the antibacterial activity to a larger extent as compared to $\mathrm{MgCl}_{2}$. At $1 \mathrm{mM}$ 


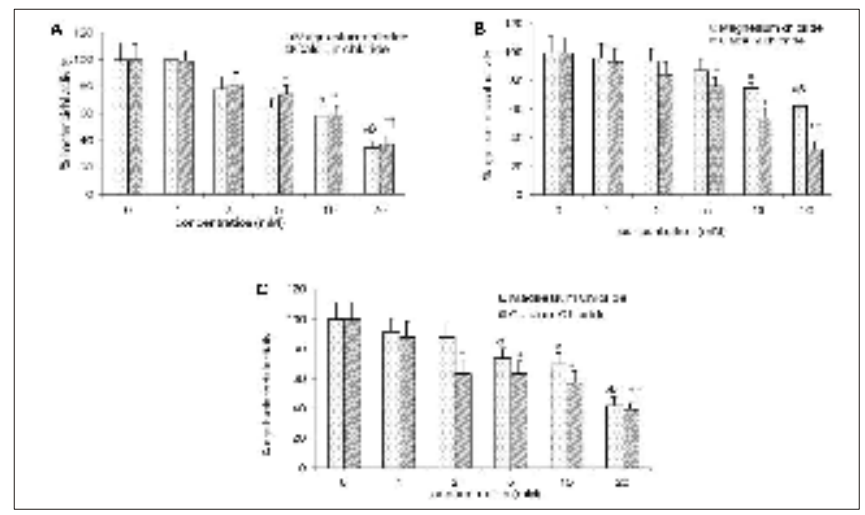

Figure-4 A). Effect of MgCl2 and CaC2 2 on antimicrobial activity of cryptdin-2 against Yenterocolitica. $\alpha p<0.05$ vs. \%age bactericidal activityat $0,1,2 \mathrm{mMMgCl} 2 ; \beta p<0.05$ vs. \%age bactericidal activity at $10 \mathrm{mMMgCl2;} * \mathrm{p}<0.05$ vs \%age bactericidal activity at $0,1 \mathrm{mM}$ $\mathrm{CaCl} 2 ; \mathrm{t}>0.05 \mathrm{vs}$. \%age bactericidal activity at $10 \mathrm{mM} \mathrm{CaCl}$; B) . Effect of $\mathrm{MgCl} 2$ and $\mathrm{CaCl} 2$ on antimicrobial activity of cryptdin-2 against S. Typhimurium $\alpha p<0.05 v s$. \%age bactericidal activityat $O$, 1, $2 \mathrm{mMMgCl} ; \beta p<0.05$ vs. \%age bactericidal activity at $10 \mathrm{mM}$ $\mathrm{MgCl} 2 ;{ }^{*}<0.05$ vs. \%age bactericidal activity in the absence of $\mathrm{CaCl} 2 ; \mathrm{t}>0.05$ vs. \%age bactericidal activity at $10 \mathrm{mMCaC2}$; C). Effect of $\mathrm{MgCl} 2$ and $\mathrm{CaCl} 2$ on antimicrobial activity of cryptdin-2 against $S$. aureus. $\alpha p<0.05$ vs. \%age bactericidal activity in the absence of $\mathrm{MgCl} 2 ; \beta p<0.05$ vs. \%age bactericidal activity at $10 \mathrm{mM}$ MgCl2; *p<0.05 vs. \%age bactericidal activity at O,1 mM CaCl2; $t_{p}<0.05 v s$. \%age bactericidal activityat $10 \mathrm{mMCaCl} 2$.

$\mathrm{CaCl}_{2}$, the reduction in activity against $S$. Typhimurium (Fig.4B), Y. enterocolitica (Fig.4A) and S. aureus (Fig. 4C) was 7\% (p>0.05), 2\% (p>0.05) and 12\% $(\mathrm{p}<0.05)$ respectively. At $2 \mathrm{mM} \mathrm{CaCl}_{2}$, greater than $80 \%$ activity was retained against $S$. Typhimurium and $Y$. enterocolitica but against $S$. aureus the activity was reduced to $63.14 \%$. However, at $20 \mathrm{mM} \mathrm{CaCl}_{2}$, the reduction was higher $(\mathrm{p}<0.05)$ i.e $63 \%, 68 \%$ and $60 \%$ against $Y$. enterocolitica, $S$. Typhimurium and $S$. aureus, respectively. The growth of bacteria in all the flasks in the absence of the peptide suggested that there was no influence of the salt on bacterial growth

\section{Effect of $p H$}

The effect of $\mathrm{pH}$ on the activity of the peptide was established by determining the MBC of each of the peptide against all the three selected strains at $\mathrm{pH}$ values varying from 5 to 8 (Fig.5).The MBC was not affected against Salmonella Typhimurium between the $\mathrm{pH}$ range of 6 to 7.5. Although the MIC of the peptide against $S$. aureus was markedly affected below $6.5 \mathrm{pH}$, but it did not change significantly against Yersinia enterocolitica between the $\mathrm{pH}$ range 5.5 to 7.5 .

\section{Antimicrobial activity in presence of trypsin}

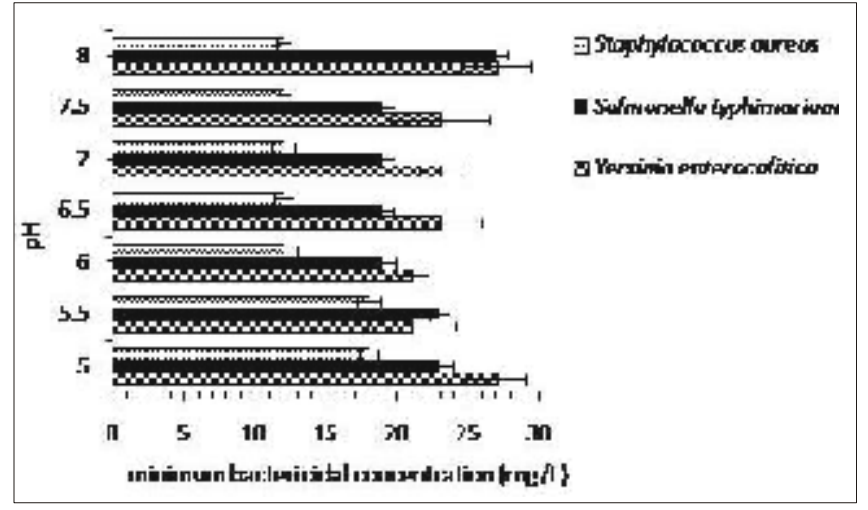

Figure-5. Minimum bactericidal concentrations of cryptdin-2 against the pathogens at various pHvalues. Values are means $\pm S D$ of three independent experiments.

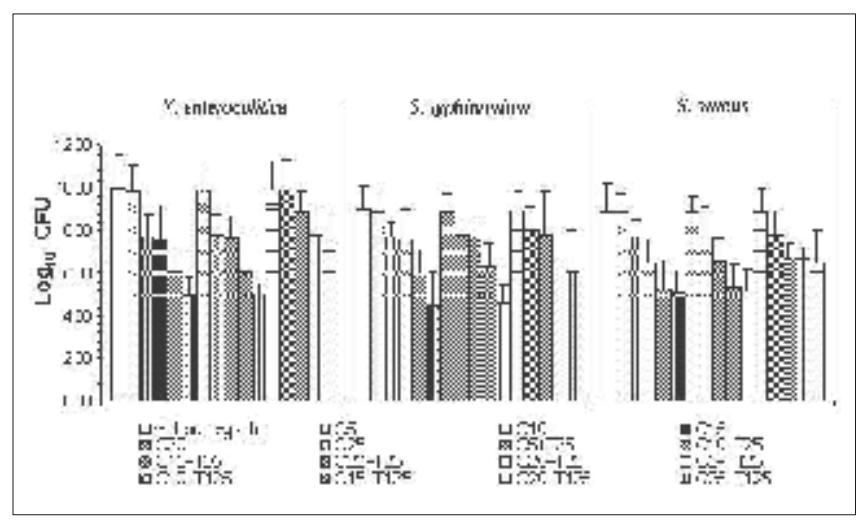

Figure-6Log10 decrease in CFU of the test pathogens by cryptdin-2 at various concentrations in presence $(25 \mu \mathrm{g} / \mathrm{ml}, \mathrm{T25} ; 125 \mu \mathrm{g} / \mathrm{ml}$, T125 of trypsinafter $3 h$. Values are means \pm SD of three independent experiments.

The antimicrobial activity of cryptdin- 2 against the bacterial strains was tested against the test pathogens in presence of 25 and $125 \mu \mathrm{g} / \mathrm{ml}$ of trypsin. No significant change ( $p>0.05)$ in the log unit decrease was observed when the bacterial cells were incubated with various concentrations of cryptdin-2 in the presence or absence of $25 \mu \mathrm{g} / \mathrm{ml}$ of trypsin indicating the relative stability of the peptide to trypsin degradation. The decrease in CFUs in presence of cryptdin-2 in a concentration dependent manner was still observed in the presence of trypsin $(125 \mu \mathrm{g} / \mathrm{ml})$ giving appx. $2.4 \log$ unit decrease in CFU of $S$. aureus and $Y$. enterocolitica while a $2.83 \log$ unit decrease was observed against $S$. Typhimurium (Fig.6)

\section{DISCUSSION}

The therapeutic success of an agent against oral or systemic infections is relative to its stability under the physiological conditions. Keeping this in view, the present study was carried out to assess the effect of various 
physiological parameters prevailing inside the dynamic host-milieu on the antimicrobial activity of cryptdin-2 against three selected pathogens i.e Salmonella Typhimurium, Y. enterocolitica and Staphylococcus aureus. The peptide was found to be active against both Gram positive and Gram negative bacteria akin to other mammalian defensins. ${ }^{12}{ }^{13}$ Comparatively, cryptdin-2 was found to be more effective against $S$. aureus than the Gram negative pathogens in concordance with our earlier report. ${ }^{14}$ This difference in susceptibility might be due to the nature of interactions between antimicrobial peptides and microbial membrane components present in Gram positive and Gram negative bacteria. Similar variation in potency against various bacterial strains has been observed earlier for murine cryptdins. ${ }^{15}$

The antibacterial activity of cryptdin- 2 against the pathogens in terms of MBC in the presence of bile salts at physiological concentrations was also evaluated. The MBCs against $S$. Typhimurium and $Y$. enterocolitica were found to be lower when the assay medium was supplemented with $0.3 \% \mathrm{w} / \mathrm{v}$ concentrations of sodium taurocholate and sodium deoxycholate. The increased antimicrobial effect with addition of bile salts may be related to the increased solubility of the peptide in presence of bile salts. ${ }^{16}$ Additionally, bile salts may also alter the structural integrity of bacterial membrane thereby enhancing the uptake of the peptide. However, no change was observed in MBC against $S$. aureus in the presence of bile salts. It might be attributed to the thick peptidoglycan layer that might be a barrier in access of bile salts to the cell membrane.

A major obstacle in the development of AMPs as novel antibiotics is the antagonism between the peptides and ionic strength (in their environment), thereby impairing the practical therapeutic use of these peptides. ${ }^{17}$ Many cationic antimicrobial peptides including HD-5, ${ }^{18,19}$ lactoferricin $\mathrm{B},{ }^{20}$ histain $5,{ }^{21}$ human cathelicidin LL-37, ${ }^{22}$ protegrins ${ }^{23}$ and pleurocidin, ${ }^{24}$ have been reported to be salt sensitive and have been shown to lose their antimicrobial activity at elevated concentrations of monoor divalent cations. In this study, the activity of cryptdin2 evaluated in presence of physiological concentrations of monovalent and divalent cations was found to be influenced by elevated concentrations of both monovalent and divalent cations. It has been suggested that the presence of cations can prevent the peptides from interacting with the membrane and subsequently neutralize the capability of peptides to kill bacteria. ${ }^{25}$
As the $\mathrm{pH}$ in small intestine ranging from $\mathrm{pH} 5$ to 8 (from proximal to distal end) ${ }^{26-28}$ can affect the activity of cryptdin-2 (by modifying the peptide or the target), the influence of $\mathrm{pH}$ changes on the activity was also monitored. The activity against all the three pathogens decreased at $\mathrm{pH}$ 5.5. It has been reported that resistance of pathogens to intestinal defensins is increased due to the upregulation of acid tolerance response systems under the acidic stress conditions as has been suggested for Salmoenlla Typhimurium. ${ }^{11}$ However, at $\mathrm{pH} 8$, no change in activity was observed against $Y$. enterocolitica and $S$. Typhimurium while it was found to be reduced against $S$. aureus. This might be attributed to the fact that properties of the bacterial targets are differentially modified by the $\mathrm{pH}$ changes. ${ }^{29-31}$ In addition, the net charge of cryptdin-2 which parallels its antimicrobial activity could also be influenced by the $\mathrm{pH}$ leading to alterations in its antibacterial activity. ${ }^{12,32,33}$

As cryptdin-2 might encounter many proteases in the luminal fluids, its stability to trypsin degradation was also evaluated in this study. Surprisingly, the peptide was able to sustain its activity against all the three test strains at physiological concentrations of trypsin. Although the activity was lesser at $125 \mu \mathrm{g} / \mathrm{ml}$ of trypsin, a $2 \log$ unit decrease was still observed in colony forming units of all the test strains. Our observations are in concordance with earlier studies which suggested that the rigid cysteine bridging motif of defensins possibly blocks the access of trypsin to susceptible sites. ${ }^{11}$ Moreover, in-vivo intracellular and secreted intestinal defensins may be further protected by trypsin inhibitors, which are also reported to be present in Paneth cells.

The persistence of the antimicrobial activity of cryptdin-2 against the pathogens under various conditions simulating the host in-vivo milieu indicates towards its possible clinical development as an effective strategy to combat bacterial infections. Effectiveness of the peptide through increased stability and protection from inactivation (particularly in reference to cations and $\mathrm{pH}$ ) may further be increased by encapsulation methods. ${ }^{34}$ These methods would also allow sustained diffusion of the active peptide and deliver a controlled dose over an extended period of time.

\section{ACKNOWLEDGEMENTS}

This work was supported by the Indian Council of Medical Research (ICMR), New Delhi, India (Grant no. 5/81(207)/D/2005/ECD-II). 


\section{Conflict of interest}

The authors declare that they have no conflict of interest

\section{REFERENCES}

1. Liu SP, Zhou L, Lakshminarayanan R, Beuerman RW. Multivalent antimicrobial peptides as therapeutics: Design, principles and structural diversities. Int J Pept Res Ther 2010; 16:199-213.

2. Dempsey CE, Hawrani A, Howe RA, Walsh TR. Amphipathic antimicrobial peptides - from biophysics to therapeutics. Protein Pept Lett 2010;17:1334-44.

3. McCormick TS, Weinberg A. Epithelial cell-derived antimicrobial peptides are multifunctional agents that bridge innate and adaptive immunity. Periodontol 2000.2010;54:195206.

4. Sharma S, Verma I, Khuller GK. Therapeutic potential of human neutrophil peptide-1 against experimental tuberculosis. Antimicrob Agents Chemother 2001;45:639-40.

5. Rodríguez TM. On the cusp of change: new therapeutic modalities for HCV. Ann Hepatol 2010;9:123-31.

6. Doss M, White MR, Tecle T, Gantz D, Crouch EC, Jung G et al. Interactions of alpha-, beta-, and theta-defensins with influenza A virus and surfactant protein D. J Immunol 2009; 182:7878-87.

7. Ouellette AJ, Hsieh MM, Nosek MT, Cano-Gauci DF, Huttner KM, Buick RN et al. Mouse Paneth cell defensins: primary structures and antibacterial activities of numerous cryptdin isoforms. Infect Immun 1994;62:5040-7.

8. Preet S, Verma I, Rishi P. Cryptdin-2: a novel therapeutic agent for experimental Salmonella Typhimurium infection. J Antimicrob Chemother 2010;65:991-4.

9. Piddock LJV, Ricci V, McLaren I, Griggs DJ. Role of mutation in the gyrA and parC genes of nalidixic-acid-resistant Salmonella serotypes isolated from animals in the United Kingdom. J Antimicrob Chemother 1998;41:635-41.

10. Rishi P, Mavi S, Bharrhan S, Shukla G, Tewari R. Protective efficacy of probiotic alone or in conjunction with a prebiotic in Salmonella-induced liver damage. FEMS Microbiol Ecol 2009;69:222-30.

11. Porter EM, Dam EV, Valore EV, Ganz T. Broad-spectrum antimicrobial activity of human intestinal defensin 5. Infect Immun 1997;65:2396-401.

12. Ouhara K, Komatsuzawa H, Yamada S, Shibra H, Fujiwara T, Ohara M et al. Susceptibilities of periodontopathogenic and cariogenic bacteria to antibacterial peptides, â-defensins and LL37, produced by human epithelial cells. J Antimicrob Chemother 2005;55:888-96.

13. Wei GX, Campagna AN, Bobek LA. Factors affecting antimicrobial activity of MUC7 12-mer, a human salivary mucinderived peptide. Ann Clin Microbiol Antimicrob 2007; 6:14.doi:10.1186/1476-0711-6-14
14. Preet S, Rishi P. Antimicrobial activity of Paneth cell derived cryptdin-2 against selected pathogens. Am J Biomed Sci 2010;2:13-22.

15. Selsted ME, Miller SI, Henschen AH, Ouellette AJ. Enteric defensins: antibiotic peptide components of intestinal host defence. J Cell Biol 1992;118:929-36.

16. Darkoh C, Lichtenberger LM, Ajami N, Dial EJ, Jiang ZD, Dupont HL et al. Bile acids improve the antimicrobial effect of rifaximin. Antimicrob Agents Chemother 2010;54: 3618-24.

17. Wu G, Ding J, Li H, Li L, Zhao R, Shen Z, et al. Effects of cations and $\mathrm{pH}$ on antimicrobial activity of thanatin and sthanatin against Escherichia coli ATCC 25922 and B. subtilis ATCC 21332. Curr Microbiol 2008;57:552-7.

18. Tomita T, Hitomi S, Nagase T, Matsui H, Matsuse T, Kimura S. Effect of ions on antibacterial activity of human beta defensin-2. Microbiol Immunol 2010;44:749-54.

19. Hoover DM, Wu Z, Tucker K, Lu W, Lubkowski J. Antimicrobial characterization of human beta-defensin-3 derivatives. Antimicrob Agents Chemother 2003;47:2804-9.

20. Bellamy W, Takase M, Wakabayashi H, Kawase K, Tomita M. Antibacterial spectrum of lactoferricin-B, a potent bactericidal peptide derived from the $\mathrm{N}$-terminal region of bovine lactoferrin. J Appl Bacteriol 1992;73:472-9.

21. Helmerhorst EJ, Breeuwer P, Hof VW, Walgreen WE, Oomen LC, Veerman EC. The cellular target of histatin-5 on Candida albicans is the energized mitochondrion. J Biol Chem 1999;274:7286-91.

22. Cox DL, Sun Y, Liu H, Lehrer RI, Shafer WM. Susceptibility of Treponema pallidum to host-derived antimicrobial peptides. Peptides 2003;24:1741-6.

23. Miyasaki KT, Iofel R, Oren A, Hyunh T, Lehrer RI. Killing of Fusobacterium nucleatum, Porphyromonas gingivalis and Prevotella intermedia by protegrins. J Periodontal Res 1998;33:91-8.

24. Cole AM, Darouiche RO, Legarda D, Connell N, Diamond G. Characterization of a fish antimicrobial peptide: gene expression, subcellular localization, and spectrum of activity. Antimicrob Agents Chemother 2000;44:2039-45.

25. Maisetta G, Luca MD, Esin S, Florio W, Brancatisano RL, Bottai D. Evaluation of the inhibitory effects of human serum components on bactericidal activity of human beta defensin-3. Peptides 2008;29:1-6.

26. Evans DF, Pye G, Bramley R, Clark AG, Dyson TJ, Hardcastle $\mathrm{JD}$, et al. Measurement of gastrointestinal $\mathrm{pH}$ profiles in normal ambulant human subjects. Gut 1988;29:1035-41.

27. Fallingborg J, Christensen LA, Nielsen MI, Jacopson BA, Abildquard K, Rasmussen $\mathrm{HH}$ et al. Measurement of gastrointestinal $\mathrm{pH}$ and regional transit times in normal children. J Pediatr Gastroenterol Nutr 1990;11:211-4.

28. McCloy RF, Greenberg GR, Baron JH. Duodenal pH in health and duodenal ulcer disease: effect of a meal, coca-cola, smoking, and cimetidine. Gut 1984;25:386-92. 
29. Shimoda M, Ohki K, Shimamoto Y, Kohashi O. Morphology of defensin-treated Staphylococcus aureus. Infect Immun 1995;63:2886-91.

30. Peschel A, Jack RW, Otto M, Collins LV, Staubitz P, Nicholson $\mathrm{G}$ et al. Staphylococcus aureus resistance to human defensins and evasion of neutrophil killing via the novel virulence factor mprF is based on modification of membrane lipids with L-lysine. J Exp Med 2001;193:1067-76.

31. Peschel A, Otto M, Jack RW, Kalbacher H, Jung G, Gotz F et al. Inactivation of the dit operon in Staphylococcus aureus confers sensitivity to defensins, protegrins, and other antimicrobial peptides. J Biol Chem 1999;274:8405-510.
32. Selsted ME, Szklarek D, Ganz T, Lehror RI. Activity of rabbit leukocyte peptides against Candida albicans. Infect Immun 1985;49:202-6.

33. Bessalle R, Haas H, Goria A, Shalit I, Fridkin M. Augmentation of the antibacterial activity of magainin by positive-charge chain extension. Antimicrob Agents Chemother 1992;36: 313-7.

34. Eby DM, Farrington KE, Johnson GR. Synthesis of bioinorganic antimicrobial peptide nanoparticles with potential therapeutic properties. Biomacromolecules 2008;9:2487-94. 


\section{PDF created with pdfFactory Pro trial version www.pdffactory.com}

